\title{
Strategy of Exclusive Dealing in Perspective the Law of Competition in Indonesia
}

\author{
Hernawan Hadi $^{1}$, Adi Sulistiyono ${ }^{2}$, Albertus Sentot Sudarwanto ${ }^{3}$ \\ ${ }^{1.2 .3}$ Universitas Sebelas Maret \\ Surakarta, Indonesia. \\ hernawanhadi@staff.uns.ac.id
}

\begin{abstract}
The purpose of this writing or research is to find out about the Closed Agreement, which is regulated in Article 15 of Law No. 5 Th, 1999, as an obstacle to fair competition that causes and causes a monopoly. The advantage that is one of his objectives on businesses, one of the strategies used by companies to achieve this is the strategy of exclusive dealing agreement, among other kinds, is complete distribution agreement, tying agreement and vertical agreement on discount, which is considered to impact negative the detriment of other businesses his or consumers which, in them paying more than the original price as a result of the dominant position. But because the exclusive agreement also has a positive impact that is guaranteed distribution of raw materials and marketing by distributors, resulting in inefficiency in production coststhe Business Competition Supervisory Commission authority issued business competition supervisory commission Regulation No.5 of 2011
\end{abstract}

Keywords- Strategy, Dealing, Indonesia.

\section{INTRODUCTION}

Open and fair competition is the fundamental premise or principle of corporate competition law. The exclusive dealing general understanding is an agreement that occurred between those who are on a different level in the production process or distribution network of goods or services regulated nature of Article 15 of Law No. 5 Th.1999 concerning prohibition of monopolistic practices and unfair business competition regulates an executive dealing, which reads business actors are prohibited from making agreements with other parties.[1]

Executive dealing is an agreement made by a business actor so that it can be a means and effort for business actors to be able to exercise control by business actors on the actor other businesses vertically (vertical control), both through price control and through non-price control, according to the Business Competition Supervisory Commission (KPPU) Regulation No. 5 of 2011, which is a guideline for Article 15 of Law No. 5 Th. 1999. The distribution of products and services is where this executive dealing method is most commonly used. [2]

The wide competition of steep competition is prohibited by Article 15 of Law No. 5 Th. 1999. However, under Article 50 letter (b) of Law No. 5 Th. 1999, agreements relating to Intellectual Property Rights, know-how, and franchise agreements are exempted. This is to offer exclusive (monopoly) rights, which are the foundation for granting Intellectual Property Rights. The
Complete Distribution Agreement in question is a business actor's agreement with another business actor that includes a requirement that the party receiving the product only enter or not re-enter the product to a specific party or location, or in other words, the distributor is forced to only enter the product to specific parties and areas by the manufacturing company. [3]

Circumstances can influence the price of a product when it enters the market. As a result, the manufacturing business made arrangements with distributors to divide the consumer and supply areas in order to avoid competition among distributors. Customers and regions may be able to decrease or even eliminate competition at the distributor level, causing the price of items distributed to be higher than the original, and consumers may have to pay more than usual to obtain a product distributed by the distributor. [4]

The risk of a business actor being killed as a result of a lack of raw materials or a distributor willing to sell his product is a concern with exclusive dealing. Aside from that, exclusive dealing can raise the hurdles to entry into the market. There is also a result of the favorable her of exclusive trading, which is beneficial to both distributors and producers. Exclusive dealing is intriguing since the distribution of a particular component is unpredictable. Exclusive dealing can also prevent free riding. For example, if there are no exclusive agreements, the parent company may conduct large-scale advertising, so when customers come to the distributor as scrambled with ads, but consumers see and buy other goods from distributors, the advertisements carried out have no effect.[5]

Law No. 5 Th. 1999 prohibits certain types of agreements, including tying agreements. The behavior of business actors can amplify the monopoly power of the linking product (goods are sold first) to the product (charcoal or services which consumers must purchase). Company A, for example, is a major player in the soap industry. The corporation wants to expand its monopolistic capacity to other items, such as shampoo, thus it is compelling consumers to buy shampoo by merging soap and shampoo products. [6]

Business actors are forbidden from creating arrangements with third parties that oblige people who acquire some goods and or services to be willing to buy other goods and or services from suppliers, according to Article 15 paragraph 2 of Law No. 5 Th. 1999. The definition of a tying agreement signed between businesses may also be found in article 15, paragraph 2 of Law No. 5 
Th. 1999, which contains the condition that the party receiving the products and services be willing to buy goods and other services from suppliers. When viewed in light of article 15 paragraph (2) UU No. 5 Th. 1999, forming a tying agreement with the formulation per se illegal, businesses that contract with other companies to practice tying agreements must consider the consequences of their actions. This article could ideally be imposed on business actors who violated it. [7]

Tying products and tried products by business players can create barriers to possible business competitors entering the market by giving them monopolistic power for both products at the same time. Inevitably, business actors must practice tying agreements as well. Consumers who do not comprehend the process of tying agreements are considered a reward when the amount paid is the price of both products. This practice can also make it difficult for consumers to determine the actual cost of the products they purchased, especially if they only want to buy one product but are forced to buy other products, which can cause consumers to become confused about the price of each product and force them to buy goods they don't need.

\section{FINDINGS AND DISCUSSION}

Business actors are prohibited from making agreements regarding specific prices or price discounts on goods and services that contain requirements that business actors who receive goods and or services from business suppliers are willing to buy goods and other services from business suppliers, or will not accept the same or similar interests and services from other business actors who are competitors with them, according to Article 15 paragraph (3) of Law No. 5 Th. 1999.[8]

This indicates that if a business actor wants a discount on a certain product acquired from a specific business actor, the business actor must be willing to buy other products from the business actor or will not believe the same or similar product from a competitor. If we look at the original article 15 , the consequences of the agreement, particularly in terms of the obligation for business operators who receive products at a discount and are then required to buy other products from the supplier's business products, are the same as those caused by tying agreements, namely, eliminating the right of businesses to freely choose the products they buy and forcing the company to buy products that the supplier wants them to buy.[9]

Obligation on businesses that receive the product at a discounted price for not going to buy the same product or a similar type of other business actor who is a competitor of the supplier business actor may result in a competing business actor having difficulty in selling similar products in the market with business actors who have previously made a vertical agreement on discount to the recipient of the product in the market. [10]

Although Article 8 of Law Number 5 of 1999 prohibits the establishment of a minimum vertical price, it will require caution in enacting a ban on price fixing minimum vertical. In competition law, it has always been cautioned against enacting a ban on price fixing minimum vertical to avoid hat as free riders, which in this case refers to parties who are unable to reap the maximum benefit from their hard-earned efforts because these benefits are taken by someone else. [11]

For example, a free raider is a person who sets a minimal price in the context of prohibition. When two parties sell the same products and brands, vertical is defined as when the retailer first has a decent outlet with a professional sales force and a good showroom. Many people hunt for information on retailers who will come first, however there are merchants that do not have a showroom and do not charge as much, but sell the same goods as the retailer who comes first. Of course, shops both can sell goods at much lower prices. In this situation, the potential consumer is more likely to seek about and search for information before going to the retailer, but once they have it, they will buy both the cheaper and the more expensive items at the retailer.[12]

Do not automatically covered agreements that have negative impacts, will be but it can also have a positive impact. Therefore, businesses cannot be punished simply for making a exclusive dealing, where the agreement covered a positive impact. The distinction between positive impacts from negative impacts can be established by (i) studying the background or reasons why the business actor makes a exclusive dealing, and (ii) analyzing the effect / impact of the exclusive dealing being made. The positive impacts of making such exclusive dealing in general include: a) Increased specialization between producers and distributors will increase the economies of scale of each party, while reducing the element of uncertainty in the distribution process. b) Reducing transaction costs between producers and distributors so that efficiency increases. c) Increased certainty in doing business for business actors who are bound in a exclusive dealing. d) Reducing distributor behavior by taking arbitrage opportunities. [13]

This happens when a person buys a sufficient number of products, then sells it to another market so that he benefits from the difference in selling prices in different markets. The impact of this arbitrage action will disrupt the market share of the same producer in other regions. While the negative impacts that can be caused by the implementation of a exclusive dealing in general include: a) Increasing market entry barriers for potential business actors and closing access for competing business actors. This obstacle occurs because business actors who are not involved in the exclusive dealing are forced to build their own distribution network or find an independent distributor. [14]

The process of finding and building a distribution network will incur integration costs and switching costs which are a significant obstacle for business actors not involved in a exclusive dealing. b) Potential for regional division. The division of this area can occur if the distribution allocation between producers-distributors into several regions, where for each region there are several dominant distributors. The form of a exclusive dealing between producers and distributors will make it easier for 
distributors to maintain their respective territories. Thus the practice of exclusive dealing can facilitate the practice of collusion in the division of territory, especially for businesses at the downstream level. c) It is possible for businesses to increase market power, which in turn will discriminate prices to maximize profits. d) For consumers, in principle is a result of competition restrictions that result in a structured market not perfect competition. In such a market, business actors will generally charge prices that are higher than competitive prices to increase profits. In such conditions the consumer must pay a more expensive price, and in general will cause welfare loss (lost profits). [15]

That the negative impact should against or in the market place. Can be seen from the effects of increasing barriers to entry into the market for potential business actor and closure of access for businesses competitor, occur zoning potentially, increase the strength of the market for certain business actors significantly, the existence of price discrimination for maximizing profit or gain so that the market becomes uncompetitive resulting in business actors in general setting higher prices so consumers must pay a higher price. [16]

In this case there are efforts to minimize the difference in regulations. Metode surveillance vertical practices generally assessed on a case by case basis where among others note the existence or absence of abuse dominant position. Therefore, the policy for implementing business competition varies greatly, in this case it must be distinguished between the practice of adverse vertical competition which is neutral or beneficial. Differences reflect the diversity of economic conditions in various countries. [17] In countries where there are few barriers to market entry, such as in the United States, vertical constraints play less role compared to countries that have more barriers. Inforce policies also influenced by differences of opinion with respect to the differences in economic theory adopted in this field and with respect to the relative terms provided by the system of competition to the freedom of action and economic justice on the one hand and the economic efficiency on the other. [18]

\section{CONCLUSION}

The comparison of Business Competition Supervisory Commission/KPPU Regulation No. 5 of 2011 is UNCTAD (United Nations Conference on Trade and Development) a multilateral institution, of which Indonesia is a member. Regarding barriers vertical then the first UNCTAD stressed that the agreement in a broad sense the relationship and fixing resale prices is considered anti-competitive version, in the comparative analysis of United State regulations with regulations Eropa to be very significant.

\section{REFERENCES}

[1] A. A. Herman and M. J. Hayat, "Management of High Secondary Education After Regional Government
Law," J. Hum. Rights, Cult. Leg. Syst., vol. 1, no. 2, pp. 395-396, 2021.

[2] Syahlan, "Effective and Efficient Synchronization in Harmonization of Regulations Indonesia," J. Hum. Rights, Cult. Leg. Syst., vol. 1, no. 1, pp. 54-70, 2021.

[3] I. G. A. K. R. Handayani, A. Sulistiyono, T. Leonard, A. Gunardi, and F. U. Najicha, "Environmental management strategy in mining activities in forest area accordance with the based justice in Indonesia," $J$. Leg. Ethical Regul. Issues, vol. 21, no. 2, 2018.

[4] Z. N. Rosidah, "Coherence of the Rules of Sharia Against Pancasila," Bestuur, vol. 8, no. 1, p. 40, 2020.

[5] D. E. Wibowo, "Ewuh Pakewuh Cultural Reconstruction to Equal Consumer Protection," J. Best., vol. 8, no. 1, pp. 1-8, 2020.

[6] R. Res, "Implementation of Parate Executie Object of Liability Juridical Overview of Mortgage," J. Hum. Rights, Cult. Leg. Syst., vol. 1, no. 1, pp. 42-53, 2021.

[7] A. Ma, "Legal Aspects of Environment in Indonesia : an Efforts to Prevent Environmental Damage and Pollution," J. Hum. Rights, Cult. Leg. Syst., vol. 1, no. 1, pp. 18-30, 2021.

[8] L. Karjoko, Z. N. Rosidah, and I. G. A. K. R. Handayani, "Refleksi Paradigma Ilmu Pengetahuan Bagi Pembangunan Hukum Pengadaan Tanah Lego," Bestuur, vol. 7, no. 2, pp. 1-14, 2019.

[9] L. Karjoko, D. W. Winarno, Z. N. Rosidah, and I. G. A. K. R. Handayani, "Spatial planning dysfunction in East Kalimantan to support green economy," Int. J. Innov. Creat. Chang., vol. 11, no. 8, pp. 259-269, 2020.

[10] M. H. Ahmadi, I. G. A. K. R. Handayani, and L. Karjoko, "Problems in law of mortgage right law number 4 Tahun 1997," Int. J. Adv. Sci. Technol., vol. 28, no. 20, pp. 321-324, 2019.

[11] L. C. Lintang, Adriano Martufi, and J.W. Ouwerker, "The Alternative Concepts of Blasphemy Law in Indonesia: Legal Comparison with Ireland and Canada," Bestuur, vol. 8, no. 2, pp. 121-128, 2020.

[12] M. Pungky and H. Wijaya, "Legislation Impediments in Reorganising Government Bodies in Indonesia," Bestuur, vol. 9, no. 1, pp. 1-16, 2021.

[13] U. K. Mishra and A. Negi, "Transgender and the Right to Employment in India: Analysing the Trajectories of Discrimination," Bestuur, vol. 9, no. 1, pp. 34-43, 2021.

[14] Saidah Fasihah Binti Che Yussoff and R. Nordin, "Freedom of Expression in Malaysia: Compatibility with the International Human Rights Standard Saidah," Bestuur, vol. 9, no. 1, pp. 44-59, 2021.

[15] H. J. Noor, K. Afkar, H. Glaser, and U. G. Mada, "Application of Sanctions Against State Administrative Officials Failing to Implement Administrative Court Decisions," Bestuur, vol. 9, no. 1, pp. 73-93, 2021.

[16] W. B. Putri et al., "Medicolegal Perspective on Physician-Induced Demand Issue," Bestuur, vol. 9, no. 1, pp. 106-124, 2021.

[17] I. G. A. K. R. Handayani, L. Karjoko, and A. K. Jaelani, "Model Pelaksanaan Putusan Mahkamah 
Konstitusi yang Eksekutabilitas Dalam Pengujian Peraturan Perundang-Undangan di Indonesia," Bestuur, vol. 7, no. 1, pp. 36-46, 2019.

[18] A. K. Jaelani, I. G. A. K. Rachmi Handayani, and L. Karjoko, "EXECUTABILITY OF THE CONSTITUTIONAL COURT DECISION REGARDING GRACE PERIOD IN THE FORMULATION OF LEGISLATION," Int. J. Adv. Sci. Technol., vol. 28, no. 15, pp. 816-823, 2019. 